\title{
Correspondence
}

\section{EARLY 19th CENTURY RUSSIAN VOYAGES THROUGH BERING STRAIT}

\author{
W. BARR \\ Department of Geography, University of Saskatchewan \\ Saskatoon, Saskatchewan, Canada S7N OWO \\ Received fanuary 1987
}

To Dr Barry Gough's interesting article in the September issue of Polar Record, on 19th century Russian activity in the Northwest Passage, may be added a note on two further Russian expeditions of the period.

The first involved the sloops Otkrytiye (Capt M. N. Vasil'yev) and and Blagonamerenny (Capt G. S. Shishmarev) in 1820 and 1821. Effectively it represented the northern detachment of the project which saw Bellingshausen: and Lazarev heading south to the Antarctic in Vostok and Mirnyy. The two sloops passed Bering Strait northward-bound in June 1820 and Otkrytiye reached $71^{\circ} 06^{\prime} \mathrm{N}$ on the Alaska Coast, ie $75 \mathrm{~km}$ beyond Cook's farthest at Ice Cape, before being forced to turn back due to ice. Both vessels tried again the following year; again Otkrytiye pushed north along the Alaskan coast to beyond Icy Cape, but again was turned back by ice. The expedition was described in detail by $A$. $P$. Lazarev, one of the officers aboard Blagonamerenny in an edited and annotated edition of his journal: Zapiski o plavanii voyennogo shlyupa 'Blagonamerennogo' $v$ Beringov proliv $i$ vokrug sveta dlya otkrytiy $v 1819,1820,1821, i 1822$ etc. Moscow, Geografgiz, 1950. The coincidence in timing with Parry's first and second voyages, and with Franklin's first overland expedition, was almost certainly not accidental.

The second was mounted in 1838 by the Russian American Company on the advice of Baron Ferdinand von Wrangel. In the summer of 1838 the brig Polifem sailed north through Bering Strati to Cape Lisburne. From here A. F. Kashevarov continued north in umiaks, surveying the coast to a point some $50 \mathrm{~km}$ east of Point Barrow before having to turn back. Kashevarov was almost certainly not aware that Thomas Simpson, sent out by the Hudson's Bay Company, had reached Point Barrow from the Mackenzie River the previous year, ie that this part of the Northwest Passage had already been 'closed'. However, Kashevarov's journal is of enormous ethnographic value; it was recently published by the Field Museum of Natural History, Chicago (Van Stone, J. W. 1977. A. F. Kashevarov's coastal explorations in Northwest Alaska, 1838. Fieldiana, Anthropo$\log y, 69)$. To assess these two expeditions in the vein of Gough's article, ie with a thorough evaluation of the national strategies behind them, would require a further full-length article. 